\section{Not the fault of Confucius}

Sir - P.-L. Chau and W. Y. Chau (Nature $385,110 ; 1997)$ dissent from a leading article (Nature 384, 197; 1996) apparently linking the lack of creativity in Korea to a culture deeply influenced by Confucian thought. But who said Confucian-influenced Asians have to be 'non-creative' or even Confucian? We in Taiwan are "proud" to report that, in response to the sheep-cloning experiment in Edinburgh (Nature 385, 810-813; 1997), some of our government officials and faculty members in leading universities here openly declared that Taiwan scientists had actually either "preconceived" the idea or "done it all". The following are some excerpts of what has been said.

"The technique is very simple. In fact, we cloned two mice several years ago." That was said by a professor at the School of Medicine, National Taiwan University (NTU). When asked how it was done, he refused to divulge any details on the astonishing ground that these details belong to a "top-secret X-file" (Central Daily News 5 March 1997, page 8).
"It is unfair to our country's scientists!", complained the deputy director of the Animal Industry Department, Council of Agriculture, Executive Yuan of Taiwan. "Why is everyone only interested in the British sheep-cloning work?" He then asserted that several institutes in Taiwan, for example the Department of Animal Sciences of NTU, the Pig Research Institute and the Taiwan Livestock Research Institute, had done similar or identical studies, and lamented that no one seemed to have noticed. To top it all, he began with praise of one "best" professor from the NTU, who apparently did his graduate work in the United Kingdom, and followed it with a startling, yet wistful, speculation: "Had this professor chosen to stay in England, it is highly probable that he would be the one basking in the glorious limelight" (The Independence Morning Post 5 March 1997, page 7).

So far, these outrageous statements have drawn no challenge from other scientists. To scientific communities in Western countries, this baseless bravado and the muted response from the science establishment here can be easily dismissed. But to us Asians, especially those of us who do scientific research here in Taiwan, it is a far more serious problem. For, first of all, as had been pointed out in the Chau letter, Confucius taught us the virtues of modesty and intellectual honesty of which such bravado is the antithesis. This behaviour, in fact, might be called "Ah-Qism" as it has all the characteristics of the antihero in Lu Xun's novel The Story of Ah-Q, an absurd parable about the Chinese populace around the 1920s. More disturbingly, the silence of the Taiwan scientific community reflects a deplorable reality. Subconsciously, Ah-Q-ism has not yet been cleansed from our national psyche. What else could explain a malady that drives them to crave for or tolerate such self-delusion? Until we have the will and the determination to do such cleansing, it is premature and perhaps even absurd to blame Confucius for our collective woes in science.

Klim King, Young-Sun Lin , Hong N. Yeung Institute of Biomedical Sciences, Academia Sinica,

Taipei, Taiwan, Republic of China

e-mail:bmkxk@alpha.sinica.edu.tw

bmyslin@ccvax.sinica.edu.tw

bmhny@ccvax.sinica.edu.tw

\section{No lack of interest}

Sir - I was both surprised and shocked by your recent comments about Edith Cresson, the European commissioner for research, education and training (Nature 385, 661; 1997). As I have myself held this post, I continue to follow the development of research policy. I have also, as chairman of a European Union panel, recently evaluated the current Framework programme and submitted a report to the commission and to the European Parliament. I have had meetings with Cresson to discuss these issues at some length, and have also had repeated contact with various key figures in the scientific community and industry directly interested in research policy and the way in which it is conducted.

I can, of course, speak only for myself, but I am surprised that you feel that the commissioner demonstrates a "shameful lack of interest in science". Cresson is moving to strengthen research policy and to increase its effectiveness and achieve better support for European competitiveness.

I should like to mention just a few of the initiatives I am aware of. Cresson set up, with her colleagues Neil Kinnock and Martin Bangemann, task forces intended to bring research workers, industrialists and users closer together in sectors such as manufacturing and cars, or in areas essential for the environment and health, such as water management, multimodal transport and research on viral diseases. Cresson also reduced bureaucracy by creating a simplified standard research contract.

As a member of the European Round Table of Industrialists, we have drawn the attention of the commission to the importance of education, and our cooperation has led to a very important initiative taken by Cresson about "learning in the information society".

Cresson has also initiated a process of consultation on an unprecedented scale as regards the future of community research policy, as part of the preparations for drawing up the commission's proposals for the fifth Framework programme. Since last summer, three successive orientation documents have been submitted for discussion to the institutions and authorities concerned, political leaders, elected representatives, research workers, industrialists and the press.

As president of the evaluation panel of the Framework programme, I can testify that Cresson's proposals do not aim to "repackage" the current Framework programme.

To blame Cresson - or indeed the commission as a whole - for the sluggishness of the Framework programme's adoption procedure is unfair, as it is the treaty on European Union, signed by the member states, that set out this procedure, as we have pointed out in our evaluation report.

I feel the criticism directed towards Cresson may be caused by the unavoidable resistance and opposition that any strong personality trying to introduce change always runs into.

\section{Etienne Davignon}

Société Générale de Belgique,

Rue Royale 308,

B-1000 Brussels, Belgium

\section{Unclothed emperor}

Sir - The postmodernist ideas about the nature of scientific knowledge described in a recent News story (Nature 385, 381; 1997) are not new and have already been overtaken by the history of science. I was educated in Czechoslovakia during the Lysenko era. Empirical genetics was considered an ideological construct of the bourgeoisie (the term then used was 'superstructure'). The "bankrupt capitalistic genetics of Mendel and Morgan" was contrasted with the "victorious proletarian genetics of Lysenko", and Mendel's experimental garden changed into a volleyball court. How the story ended, everybody knows. The emperor of postmodernist sociology of science not only has no clothes, he is not even new and original in his nakedness.

\section{Viktor Holoubek}

Department of Human Biological

Chemistry and Genetics,

University of Texas Medical Branch,

Galveston, Texas 77555, USA

e-mail:vholoube@mspo1.med.utmb.edu 